\title{
Access to Justice for Children, an Evolving Concept
}

\section{Prof. Dr. Migena Leskoviku}

Profesor, University of Tirana

\section{Dr. Mirgen Prence}

Lecturer, Public Law Department, European University of Tirana

Doi:10.5901/mjss.2015.v6n3p103

\begin{abstract}
Nowadays, the access to justice for children has gained widely importance and has been addressed at the international as well as the domestic level. In the last decades this concept is further developed which led to considerable modifications and further revision of international and European legal framework and thus directly affecting the domestic legal systems and policies in place. Access to justice for children is affected by social and cultural practices that should aim to enable children to seek justice without fearing of any kind of discrimination, discriminatory practices and stigmatization. What is worth mentioning is the approach that combines the need to always guarantee the rights of the child in relation to information, participation and representation in administrative and judicial proceedings, recognizing these rights in all stages of the proceedings, considering that the private life, interests, special needs, individual dignity of the child must be respected, protected and further promoted. Part of this approach are also the legal and institutional reforms within the justice system and institutional organizations of professionals and services in a number of countries, including Albania. It is not enough to have laws and adopt a legal framework that formally outline and prescribe children's rights and that tries to address their needs. These ought to be accompanied by applicable effective interventions and mechanisms that allow all children to gain the awareness and resources required to access the justice system, with no discrimination or prejudices.
\end{abstract}

Keywords: access to justice, equitability, children's rights, rule of law, international and European treaties

\section{The Concept of Access to Justice for Children and Its Dimensions}

Children's access to justice in the international and European area is an evolving concept widely affected by legal and administrative frameworks, the approach to child-sensitive issues in civil and administrative processes, and general resources available. Particular attention must be paid to the most excluded, vulnerable groups, the poor, and the most difficult to reach, recognizing that these children often face particular challenges regarding access to justice and therefore it is important that their voice is heard. Over the last few decades, the concept of access to justice has evolved from a right to take legal action for violation of rights into a term that more broadly encompasses equitable and just remedies. ${ }^{1}$ Bridging procedural justice and substantive justice, access to justice is strictly interconnected to the right to justice, as articulated in international and regional human rights standards. Access to justice for children means challenging violations of children's rights and ensuring that the law and justice systems work for children. Equitable access to justice means ensuring that all children, including those who are disadvantaged or vulnerable, are served and protected by justice systems. In many countries, justice systems, both formal and informal and judicial and non-judicial, are unaware of children's needs and ill-equipped to address them².

\footnotetext{
${ }^{1}$ Access to justice is defined by the United Nations Development Programme (UNDP) as "the ability of people to seek and obtain a remedy through formal or informal institutions of justice, in conformity with human rights standards." A more recent practitioners' definition has also been suggested by UNDP: "the right of individuals and groups to obtain a quick, effective and fair response to protect their rights, prevent or solve disputes and control the abuse of power, through a transparent and efficient process, in which mechanisms are available, affordable and accountable." See for further reading United Nations Children's Fund (UNICEF), The Regional Office for CEE/CIS, 'Children's Equitable Access to Justice', Central and Eastern Europe and Central Asia, UNICEF, Geneva, 2015, p.18. UNDP Justice System Programme, 'Access to Justice Concept Note', 2011, p.2.

2 United Nations Children's Fund (UNICEF), The Regional Office for CEE/CIS, 'Children's Equitable Access to Justice', Central and Eastern Europe and Central Asia, UNICEF, Geneva, 2015, p.18.
} 
Access to justice is also an integral part of any good rule of law framework ${ }^{3}$. In 2012, the High-Level Meeting of the UN General Assembly on the Rule of Law "recognized the importance of the rule of law for the protection of the rights of the child, including legal protection from discrimination, violence, abuse and exploitation." Increasingly, the rule of law is also seen as a prerequisite to sustainable development, the decrease of poverty, and greater equality. Access to Justice is also part of the Post- 2015 Development Agenda considered also as a tool to combat poverty and tackle the barriers of inequalities in today's social, economic and cultural environment ${ }^{4}$.

It is shown that very often, children face laws, policies and practices that are not adapted to children's experiences or otherwise lend themselves to unjust results in criminal matters, family disputes, including domestic violence, etc. Access to justice must be equitable in its implementation, not only in form to meet children's needs. Further, beyond the justice sector, changes are needed across the spectrum of child services so that children obtain an understanding of their rights, are able to access services, and seek justice. Where poverty is a factor, children are even less likely to approach the justice system to claim their rights: the stigma of poverty and the multi-dimensional deprivations suffered by the poor or those excluded and marginalized on other grounds such as disability, gender or ethnicity are enhanced by the child's dependent status 5 .

\section{Children's Access to Justice as an Integral Part of the International and European Human Rights Framework}

For the purpose of this paper, it is essential to consider the relevant international and regional human rights norms that have developed over time. These norms guide law and policy through binding legal obligations, guidelines, best practices, and recommendations. The concept of access to justice is an evolving one, and even more so with respect to children ${ }^{6}$. The basis of the right to access justice can be found in the main international human rights instruments including the Universal Declaration on Human Rights (UDHR) ${ }^{7}$ and the International Covenant on Civil and Political Rights (ICCPR) and the International Covenant on Economic, Social and Cultural Rights (ICESCR). These human rights instruments recognize the right of an individual to take legal action to defend their rights, when these rights have been violated.

The Universal Declaration of Human Rights enshrines the notion of access to justice. Thus, article 8 of the UDHR provides that: "Everyone has the right to an effective remedy by the competent national tribunals for acts violating the fundamental rights granted him by the constitution or by law." Article 10 UDHR confirms that: "Everyone is entitled in full equality to a fair and public hearing by an independent and impartial tribunal, in the determination of his rights and obligations and of any criminal charge against him", without excluding persons of any age ${ }^{8}$.

The ICCPR reaffirms this right. While the UDHR refers to the right to a remedy for violations of rights recognised by national constitution and law, Article 2 of the ICCPR recognises the right to a remedy for internationally recognised human rights. Article 14 recognises the right of access to courts, in particular, for a fair hearing on issues concerning any legally recognised right. This right, as recognised by Article 14, is not limited to human rights violations, but covers practically any issue concerning any legal right, regardless of whether the other party is a public official, private individual, corporation, or any other entity. Article 26 of the ICCPR confirms the principle of non-discrimination and equality in this context: "All persons are equal before the law and are entitled without any discrimination to the equal protection of the law." Access to justice must be seen also from the perspective of realizing children's economic, social and cultural rights as foreseen also in the International Covenant on Economic, Social and Cultural Rights (ICESCR). With respect to children in particular, the ICESCR codifies children's right to education and protection from social and economic exploitation.

\footnotetext{
${ }^{3}$ In the United Nations definition, the rule of law is a "principle of governance in which all persons, institutions and entities, public and private, including the State itself, are accountable to laws that are publicly promulgated, equally enforced and independently adjudicated, and which are consistent with international human rights norms and standards." United Nations, 'Guidance Note of the Secretary General UN Approach to Rule of Law Assistance', 2008. See for further information: United Nations Children's Fund (UNICEF), The Regional Office for CEE/CIS, 'Children's Equitable Access to Justice', Central and Eastern Europe and Central Asia, UNICEF, Geneva, 2015, p.18.

4 "A life of dignity for all: accelerating progress towards the Millennium Development Goals and advancing the United Nations development agenda beyond 2015", Report of the Secretary General, Sixty-eighth session of UN General Assembly, A/68/202, 26 July 2013, retrieved from https://www.unodc.org/documents/about-unodc/Post-2015-Development-Agenda/A_Life_of_Dignity_for_All1.pdf. ${ }_{5}$ United Nations Children's Fund (UNICEF), The Regional Office for CEE/CIS, 'Children's Equitable Access to Justice', Central and Eastern Europe and Central Asia, UNICEF, Geneva, 2015, p.19

6 United Nations Children's Fund (UNICEF), The Regional Office for CEE/CIS, 'Children's Equitable Access to Justice', Central and Eastern Europe and Central Asia, UNICEF, Geneva, 2015, p.22

7 Universal Declaration of Human Rights, art 8.

8 United Nations Children's Fund (UNICEF), The Regional Office for CEE/CIS, 'Children's Equitable Access to Justice', Central and Eastern Europe and Central Asia, UNICEF, Geneva, 2015, p.23.

$9 \mathrm{lbid}$.
} 
One of the late acts adopted by the UN General Assembly is the UN Guidelines for the Alternative Care of Children ${ }^{10}$ aiming to strengthen the ties between the parents/families and children, confirming that children should be placed in alternative care only in cases of necessity, providing for a range of options including foster care, other family-based environments, or residential care, where always the decision/option chosen should meet the best interests of the child in a specific case. Other International instruments and treaties deal with children's rights, as well, but of course the core one remains the UN Convention on the Rights of the Child (CRC) with the principle of the best interests of the child considered as one of the fundamental principles to guide all the procedures and policies regarding children and their access to justice. It has also created specific complaint mechanisms should these obligations not be met, for instance, The Optional Protocol to the Convention on the rights of the child on the sale of children, child prostitution and child pornography and The Third Optional Protocol to the Convention on the Rights of the Child on a communications procedure. ${ }^{11}$

Article 3 of the CRC is particularly pertinent to issues concerning remedies and decisions taking on behalf of children. It provides that in "all actions concerning children, whether undertaken by public or private social welfare institutions, courts of law, administrative authorities or legislative bodies, the best interests of the child shall be a primary consideration". 12 It also provides that "States Parties undertake to ensure the child such protection and care as is necessary for his or her well-being, taking into account the rights and duties of his or her parents, legal guardians, or other individuals legally responsible for him or her, and, to this end, shall take all appropriate legislative and administrative measures" as well as that every State party "shall ensure that the institutions, services and facilities responsible for the care or protection of children shall conform with the standards established by competent authorities, particularly in the areas of safety, health, in the number and suitability of their staff, as well as competent supervision". Access to justice for children encompasses the right to be heard, to participate in legal proceedings and to be protected, according to the provisions of this Convention ${ }^{13}$. A number of other CRC provisions seek to ensure that children enjoy access to justice and provide for effective remedies in place.

European regional human rights instruments incorporate access to justice provisions pertaining to the rights of the child, reinforcing the international human rights framework and providing an additional layer of protection and opportunity for redress. ${ }^{14}$ Briefly, the Council of Europe and European Union's standards in this area will also be mentioned, as they are increasingly relevant in the region. The Lisbon Treaty makes it clear that the European Union will be directed by the following principles: democracy, rule of law, versatility and indivisibility of human rights and fundamental freedoms, respect human dignity, the principles of equality and solidarity, and respect for the principles of the United Nations Charter and international law. These principles are reinforced by the Charter of Fundamental Rights of the EU, which includes all of these rights in a single text, and has a binding force to the Member State. Further on, there is a special provision of the EU Charter of Fundamental Rights that is dedicated to the children. It states:

\section{"1. Children shall have the right to such protection and care as is necessary for their well-being. They may express their views freely. Such views shall be taken into consideration on matters which concern them in accordance with their age and maturity. 2. In all actions relating to children, whether taken by public authorities or private institutions, the child's best interests must be a primary consideration. 3. Every child shall have the right to maintain on a regular basis a personal relationship and direct contact with both his or her parents, unless that is contrary to his or her interests". ${ }^{15}$}

Furthermore, the European Convention on Human Rights and Fundamental Freedoms (ECHR) and the respective jurisprudence of the Strasbourg Court are of paramount importance and have contributed to a better understanding of

10 UN Guidelines for the Alternative Care of Children were adopted by the UN General Assembly on the 65th plenary meeting, 18 December 2009. See also http://www. alternativecareguidelines.org.

${ }^{11}$ The protocol is a significant development that allows children or those representing the child, in countries which have ratified the protocol, to submit individual complaints about rights violations under the CRC or the OPSC to the Committee on the Rights of the Child. Albania has ratified this protocol, too.

12 In determining 'best interests', all the legal rights of the child as well as their individual circumstances must be taken into account. Determining best interest should involve adequate child participation without discrimination, due weight to be given to the views of the child and input from decision makers with relevant areas of expertise.

See also: Committee on the Rights of the Child, General Comment No. 14 on the right of the child to have his or her best interests taken as a primary consideration, 2013, CRC/C/GC/14.

${ }^{13}$ Children have the right to express their views freely on all matters affecting them. Article 12(2) provides that: "the child shall in particular be provided the opportunity to be heard in any judicial and administrative proceedings affecting the child, either directly or through a representative or an appropriate body, in a manner consistent with the procedural rules of national law".

${ }^{14}$ For example, see the European Convention on the Exercise of Children's Rights and European Convention on Human Rights.

${ }^{15}$ Article 24: "The rights of the child", Charter of the Fundamental Rights of the EU, Official Journal of the European Union, http://eurlex.europa.eu/legal-content. 
fundamental rights and freedoms enshrined in the Convention and developing practice on a case-by-case base. The EU Charter should be consistent with ECHR. Though not yet formally ratified by EU, the importance of ECHR and its developing and dynamic case-law practice solidified by the European Court of Human Rights (ECtHR) is well recognized by the EU Charter itself ${ }^{16}$.

ECHR applies to children and adults alike and it recognises the right to an effective remedy ${ }^{17}$. Although not addressing direct provisions dedicated to children only, still some of ECHR articles such as: articles 3, 5, 6, 8 often in conjunction with article 13 or 14 have been mostly associated with children in relevant cases presented to the Court. This developing and dynamic practice has contributed to well-defined regional standards obligatory to be domestically implemented by the Contracting States of the Convention. Article 14 ECHR 'Prohibition of discrimination' confirms that "the enjoyment of the rights and freedoms set forth in this Convention shall be secured without discrimination on any ground such as sex, race, colour, language, religion, political or other opinion, national or social origin, association with a national minority, property, birth or other status". However, according to the established case-law of the Court, Article 14 of the Convention complements the other substantive provisions of the Convention and its Protocols. It has no independent existence since it has effect solely in relation to "the enjoyment of the rights and freedoms" safeguarded by those provisions ${ }^{18}$. Children are not excluded from lodging an application with the court by virtue of their age, and while difficulties could arise when considering whether the child has exhausted all means for domestic remedies, the Court's practice has been to have a "benevolent attitude towards access by minors". ${ }^{19}$ The Court stated: "Children and other vulnerable individuals, in particular, are entitled to State protection, in the form of effective deterrence, against such serious breaches of personal integrity". This approach has been followed in several cases concerning neglect, physical and sexual abuse ${ }^{20}$. The Court has taken the view that principles of child-friendly justice must be applied in national courts, and has made clear that a child must be "dealt with in a manner which takes full account of his age, level of maturity and intellectual and emotional capacities, and that steps are taken to promote his ability to understand and participate in the proceedings, including conducting the hearing in such a way as to reduce as far as possible his feelings of intimidation and inhibition."21

Furthermore, the reforms and positive developments introduced by Protocol No.14 to the ECHR contributed to modernize the Court's case-processing and administrative procedures. Moreover, two other Protocols No.15 and 16 to the Convention are considered as positive steps forward concerning the rights, principles and values enshrined in the $\mathrm{ECHR}^{22}$ (including the children's rights). Protocol No. 15 to the Convention introduces a reference to the principle of subsidiarity and the doctrine of the margin of appreciation as provided for by the Court's case-law. It also reduces from six to four months the time-limit within which an application may be made to the Court following the date of a final domestic decision. While, Protocol No. 16 aims to extend the jurisdiction of the European Court of Human Rights to give advisory legal opinions on Convention and its Protocols to national courts when required, always considering the effectiveness of ECHR control mechanism and to enhance and enforce the dialogue between courts.

The jurisprudence of the Strasbourg Court offers a variety of occasions in cases implicating the implementation of

\footnotetext{
${ }^{16}$ See the Preamble of the Charter. Also Article 53 of EU Charter titled 'Level of protection' confirms: "Nothing in this Charter shall be interpreted as restricting or adversely affecting human rights and fundamental freedoms as recognised, in their respective fields of application, by Union law and international law and by international agreements to which the Union or all the Member States are party, including the European Convention for the Protection of Human Rights and Fundamental Freedoms, and by the Member States' constitutions."

${ }^{17}$ Article 13 'Right to an effective remedy' of ECHR reads: Everyone whose rights and freedoms as set forth in this Convention are violated shall have an effective remedy before a national authority notwithstanding that the violation has been committed by persons acting in an official capacity.

18 Fabris v. France, European Court of Human Rights (2013), para. 47.

19 United Nations Children's Fund (UNICEF), The Regional Office for CEE/CIS, 'Children's Equitable Access to Justice', Central and Eastern Europe and Central Asia, UNICEF, Geneva, 2015, p. 28-29. Council of Europe, 'International Justice for Children', 2008, p. 71. 20For example from ECtHR, see Stubbings and Others vs. the United Kingdom (1996); Scozzari and Giunta v. Italy, (2000); Z and others v. UK (2001); Michaud v. France (2012); Fabris v.France (2013), etc.

${ }^{21}$ S.C. $v$ the United Kingdom, No. 60958/00, European Court of Human Rights, 15 June 2004. See further: United Nations Children's Fund (UNICEF), The Regional Office for CEE/CIS, 'Children's Equitable Access to Justice', Central and Eastern Europe and Central Asia, UNICEF, Geneva, 2015, p.29.

22 Protocol No. 15 amending the Convention for the Protection of Human Rights and Fundamental Freedoms, was opened for signature by the High Contracting Parties to Treaty on 24/06/2013 and so far there are 36 ratifications/accessions by the Members States of CoE; see: $h$ ttp://www.coe.int/en/web/conventions/full-list/-/conventions/treaty/213/signatures. Protocol No. 16 amending the Convention for the Protection of Human Rights and Fundamental Freedoms, was opened for signature by the High Contracting Parties to Treaty on 02/10/2013 and so far there are 8 ratifications/accessions by the Members States of CoE. See http://www.coe.int/en/web/conventions/full-list/-/conventions/treaty/214/signatures.
} 
human rights for children. What is worth mentioning is the approach that combines the need to always guarantee the rights of the child in relation to information, participation and representation in administrative and judicial proceedings, recognizing these rights in all stages of the proceedings, considering that the private life, interests, special needs, individual dignity of the child must be respected and protected ${ }^{23}$. Considering the international corpus of norms on children rights, when dealing with certain cases, the Strasbourg Court has made a direct reference to the obligation of a State to meet the obligation deriving from the international law and standards in the field of children's rights and justice for children. For example, in Bajrami v. Albania (2006), the Court underlined that the ECHR must be applied in accordance with the principles of international law, in particular with those relating to the international protection of human rights ${ }^{24}$. The Court has also been instrumental in advancing children's access to remedies with respect to the right to education, right to respect for family life, right to privacy, and right to be free from discrimination. ${ }^{25}$ For example in $D . H$. and Others $v$. Czech Republic (ECtHR, 2007), for the first time the Strasbourg Court ruled on a discrimination case of Roma children regarding the right to education, thus referring to Article 14 of the ECHR in conjunction with Article 2 of Protocol 1 to the Convention. To put it into a more general perspective, this judgment represents a new development in the Court's caselaw, as it set about evaluating and criticizing a country's entire education system ${ }^{26}$ (focused on Roma children). Because of this judgment the whole policy/attitude and institutional organization of schooling of certain vulnerable groups of children changed, in order to avoid the previous discriminatory practice of children of a minority group. The Court stated:

\begin{abstract}
"The Court reiterates, that by virtue of Article 46 of the Convention the High Contracting Parties have undertaken to abide by the final judgments of the Court in any case to which they are parties, execution being supervised by the Committee of Ministers. It follows, inter alia, that a judgment in which the Court finds a breach imposes on the respondent State a legal obligation not just to pay those concerned the sums awarded by way of just satisfaction under Article 41, but also to select, subject to supervision by the Committee of Ministers, the general and/or, if appropriate, individual measures to be adopted in their domestic legal order to put an end to the violation found by the Court and to redress so far as possible the effects. However, the respondent State remains free to choose the means by which it will discharge its legal obligation under Article 46 of the Convention, provided that such means are compatible with the conclusions set out in the Court's judgment...... The Court notes in this connection that the legislation impugned in the instant case has been repealed and that the Committee of Ministers recently made recommendations to the member States on the education of Roma/Gypsy children in Europe ......" 27.
\end{abstract}

The ECHR provisions, as interpreted by the Strasbourg Court, also obliges the Contracting States to prevent violence against children and requires for the preventive measures to protect the child's physical and sexual integrity and dignity; on the other hand, the domestic authorities are obliged to effectively investigate any allegation of ill-treatment in the family sphere or within guardianship institutions and punish abusers. The case law of the ECtHR emphasizes both the requirement to protect the child's interests and the role of families regarding the children care as well as the effective policies and mechanisms in place to properly address the children's needs and their legitimate interests ${ }^{28}$.

Additionally, other regional instruments such as the European Social Charter (revised), European Convention on the Exercise of Children's Rights and the CoE Guidelines of the Committee of Ministers of the Council of Europe on childfriendly justice should be mentioned in this regard29, always considering the best interest of the child as a primary consideration when addressing the children's issues.

This paper could not be exhaustive on international and European acts as there are numerous ones and children's rights in the context of access to justice have been further articulated by other international and regional treaty monitoring bodies through general comments and concluding observations. Additionally, while not binding in the same manner as treaty instruments, international and regional guidelines support and further clarify this framework. Key examples of such

\footnotetext{
${ }^{23}$ Migena Leskoviku, "Albanian legislation on prevention of violence against the children in Albania. Its harmonization with European standards", paper presented in the National Conference 'Violence against children in Albania', organized by UNICEF and other partners, Tirane, November 2012 (Albanian version)

${ }^{24}$ Bajrami v. Albania, ECtHR (2006), para.55.

${ }^{25}$ For example see Bajrami v. Albania, ECtHR (2006); See also D.H. and Others v. The Czech Republic, ECtHR (2007), etc.

${ }^{26}$ See D.H. and Others v. The Czech Republic, ECtHR (2007), Dissenting Opinion of Judge Jungwiert, p. 75.

${ }^{27}$ D.H. and Others v. The Czech Republic, European Court of Human Right, (2007), para.216.

${ }^{28}$ See for example Fabris v. France, ECtHR (2013), Michaud v. France ECtHR (2012); S.C. v United Kingdom, ECtHR (2004); Z and others v. UK ECtHR (2001), Scozzari and Giunta v. Italy, ECtHR (2000); Stubbings and Others vs. the United Kingdom, ECtHR (1996), etc.

${ }^{29}$ European Social Charter, adopted 1961 (ETS 035), revised 3 May 1996 (ETS 163), revision entered into force on 1 July 1999 (Albania has ratified the European Social Charter, but it has not accepted the optional collective complaints procedure); European Convention on the Exercise of Children's Rights, 1996 (ratified by Albania in 2011, enforced in 2012); Guidelines of the Committee of Ministers of the Council of Europe on child-friendly justice, adopted by Committee of Ministers of the Council of Europe (2010).
} 
guidelines are those on child-sensitive or child-friendly approaches ${ }^{30}$.

The practice shows that the justice experience for children does not always reflect the legal and policy framework in place in a given country. Overall, access to justice for children is largely affected by their age and consequent dependent status, as well as by cultural perceptions of children's place in society and within the family. Due to their evolving capacity, children have less knowledge, fewer financial resources and are generally less-equipped to deal with the complexity of the justice system, in all its forms. They depend on adults to receive information regarding their rights, to approach and understand available remedies and to access justice fora and mechanisms. Children also need support from parents or guardians to file complaints as they do not have legal capacity or standing below certain ages ${ }^{31}$.

\section{Final Remarks/Conclusions}

Looking at access to justice for children as an integral component of the rule of law and globally addressed also at the Post-2015 Development Agenda, the focus is put on the legal, policy and institutional frameworks, reflecting on whether this framework is aligned to international standards and implemented effectively for children, and looking at how children, especially those in vulnerable situations, experience justice. Albania has ratified the main international and European instruments on this regard, as mentioned above, thus adopting them within the domestic legislation. Under the Constitution of Albania, there are a certain number of protections which specifically address the rights of children. For example Art. 54(3) of Albanian Constitution provides that every child has the right to protection from violence, illtreatment, exploitation and his or her use for work, especially under the minimum age for work, which could damage their health and morals or endanger his or her life or normal development. Several laws are adopted and/or amended and are actually enforced mentioning here one of them dedicated specifically to the rights of children, a new law "On the rights and protection of children" that replaced the previous law 'On the Protection of the Rights of the Child' 32 . The new law determines the rights and protection that every child enjoys and is entitled of, the responsible mechanisms and competent authorities, which effectively guarantee the exercise, respect, and promotion of these rights, as well as the special protection of the child, in compliance with the provisions of Constitution, the Convention on the Rights of the Child, and its Optional Protocols, other international treaties and legislation in force. The law calls for cooperation between structures and public authorities, as well as with organizations that protect the rights of the child; as well as provides for effective mechanisms and functioning of the institutions vested with power to undertake concrete measures to promote, respect and protect the rights of the child, and to set up an integrated and functional child protection system for effective prevention and response to all forms of violence, abuse, exploitation and neglect ${ }^{33}$. Other changes are made effective in this regard, such as: the Law 'On the services of social care in the Republic of Albania', ${ }^{4}$ aiming to reorganize and improve the social care services within the country, with a special focus on alternative care for children and certain categories of them and a New Code on Criminal Justice for Minors. ${ }^{35}$ The children issues and policies concerns a whole range of decisions by a whole range of people - not just police, lawyers and judges - which affect them in various ways, in terms of family, education, identity, or immigration status. Distrust of institutions and of those tasked with supporting children remains pervasive, reflecting cultural realities and social and cultural approaches that prevent children from making full use of the justice system ${ }^{36}$.

To properly address the issues discussed above on Access to Justice for children one should focus on at least three key factors affecting children's empowerment in justice processes ${ }^{37}:$ a) Knowledge of the law, legal procedures, and available judicial and non-judicial complaint mechanisms. b) economic, social and cultural practices that perpetuate inequality in the community and in societies at large and that make it acceptable for children to bring about a complaint

\footnotetext{
${ }^{30}$ The Report of the United Nations High Commissioner for Human Rights, Access to Justice for Children, treats these terms as synonymous and they are used as such in this paper. See also United Nations Children's Fund (UNICEF), The Regional Office for CEE/CIS, 'Children's Equitable Access to Justice', Central and Eastern Europe and Central Asia, UNICEF, Geneva, 2015.

${ }^{31}$ United Nations Children's Fund (UNICEF), The Regional Office for CEE/CIS, 'Children's Equitable Access to Justice', Central and Eastern Europe and Central Asia, UNICEF, Geneva, 2015, p.9.

32Law No. 18/2017 "On the rights and protection of children" replaced the former law no. 10347 date 4.11.2010 "On the Protection of Children' Rights".

${ }^{33}$ Article 1 and 2 of the Law No. 18/2017 "On the rights and protection of children".

${ }^{34}$ Law No. 121/2016 "On the Services of Social Care in the Republic Of Albania"

${ }^{35}$ Law No. 37/2017 "Code of the Criminal Justice for Minors" will enter into force on the 1st of January 2018.

${ }^{36}$ United Nations Children's Fund (UNICEF), The Regional Office for CEE/CIS, 'Children's Equitable Access to Justice', Central and Eastern Europe and Central Asia, UNICEF, Geneva, 2015, p.118.

${ }^{37} \mathrm{lbid}$, p.50.
} 
against family or community members. c) Justice mechanisms in place and process which must be child-sensitive, to protect all children from discrimination, and to provide effective support services.

In order to improve access to justice for children, public authorities need to look critically at the whole spectrum of child services linked in one way or another to the justice system: not only police or courts, but also teachers, social workers, psychologists and community stakeholders, all of whom interact with children in their pathways to justice ${ }^{38}$. Despite international treaties and their adoption within the domestic legal system, and thus the legislative and policy frameworks are generally developing, important gaps and concerns remain, especially when it comes to the implementation phase of the law, the institutional and organization aspect, human and financial resources but also concerning civil and administrative matters. Another problem regards the transfer of certain powers and tasks to local units/governments and effective coordination among the various competent stakeholders within or out of the justice system.

\section{References}

Constitution of the Republic of Albania (1998)

Law No. 121/2016 "On the Services of Social Care in the Republic Of Albania", available at: www.qpz.gov.al

Law No. 18/2017 "On the rights and protection of children", available at: www.qpz.gov.al

Law No. 37/2017 "Code of the Criminal Justice for Minors"

Law No. 10347 date 4.11.2010 "On the Protection of Children' Rights",

UNDP Justice System Program (2011).'Access to Justice Concept Note'.

United Nations Children's Fund (UNICEF), The Regional Office for CEE/CIS, 'Children's Equitable Access to Justice', Central and Eastern Europe and Central Asia, UNICEF, Geneva, 2015.

United Nations (2008). 'Common Approach to Justice for Children'.

United Nations,(2008).' 'Guidance Note of the Secretary General UN Approach to Rule of Law Assistance'.

Report of the United Nations High Commissioner for Human Rights (December 2013) 'Access to Justice for Children'.

"A life of dignity for all: accelerating progress towards the Millennium Development Goals and advancing the United Nations development agenda beyond 2015", Report of the Secretary General, Sixty-eighth session of UN General Assembly, A/68/202, 26 July 2013.

Committee on the Rights of the Child (2013).General Comment No. 14 on the right of the child to have his or her best interests taken as a primary consideration, CRC/C/GC/14.

Council of Europe (2008).'International Justice for Children'.

Migena Leskoviku, "Albanian legislation on prevention of violence against the children in Albania. Its harmonization with European standards",paper presented in the National Conference 'Violence against children in Albania', organized by UNICEF and other partners, Tirane, November 2012 (Albanian version)

\section{International and European Treaties}

The Universal Declaration of Human Rights (UDHR), (1948)

UN Convention on the Rights of the Child, (UNCRC) 1989, (ratified by Albania on 27 February 1992).

International Covenant on Civil and Political Rights (ICCPR), 1966 (ratified by Albania in October 1991).

International Covenant on Economic, Social and Cultural Rights (ICESCR), 1966(ratified by Albania in October 1991).

UN Guidelines for the Alternative Care of Children adopted by the UN General Assembly on the 65th plenary meeting, 18 December 2009.

European Convention on Human Rights and Fundamental Freedoms, adopted by Council of Europe, 1950 (ratified by Albania on 2 October 1996) and its Protocols No. 15 and 16.

European Social Charter (revised), (ratified by Albania in 2002).

European Convention on the Exercise of Children's Rights, 1996 (ratified by Albania in 2011, enforced in 2012).

Guidelines of the Committee of Ministers of the Council of Europe on child-friendly justice, adopted by Committee of Ministers of the Council of Europe (2010).

\section{Case-law of the European Court of Human Rights}

Fabris v. France (2013),European Court of Human Rights Michaud v. France (2012), European Court of Human Rights.

D.H. and Others v. the Czech Republic, (2007), European Court of Human Rights.

Bajrami v. Albania (2006), European Court of Human Rights.

S.C. v United Kingdom, (2004), European Court of Human Rights.

$Z$ and others v. UK (2001), European Court of Human Rights

Scozzari and Giunta v. Italy, (2000), European Court of Human Rights

Stubbings and Others vs. the United Kingdom (1996), European Court of Human Rights.

${ }^{38} \mathrm{lbid,} \mathrm{.p.} 116$. 